\title{
Microhabitat heterogeneity associated with Vanilla spp. and its influences on the microbial community of leaf litter and soil
}

\author{
Gabriela Montes de Oca-Vásquez ${ }^{1}$, Frank Solano-Campos ${ }^{2, *}$, Bernal Azofeifa-Bolaños ${ }^{2,3}$, \\ Amelia Paniagua-Vasquez ${ }^{4}$, José Vega-Baudrit ${ }^{1,5}$, Antonio Ruiz-Navarro ${ }^{6}$, \\ Rubén López-Mondéjar ${ }^{7}$, Felipe Bastida ${ }^{6}$ \\ 1 National Nanotechnology Laboratory, National Center for High Technology, 10109 Pavas, San José, Costa Rica \\ 2 School of Biological Sciences, Universidad Nacional, Campus Omar Dengo, 86-3000 Heredia, Costa Rica \\ 3 Asociación Nacional de Vainilleros Unidos, San José, Costa Rica \\ 4 Instituto de Investigación y Servicios Forestales, Universidad Nacional, 86-3000 Heredia, Costa Rica \\ 5 Laboratory of Polymer Science and Technology, School of Chemistry, Universidad Nacional, Campus Omar Dengo, 86-3000 Heredia, \\ Costa Rica \\ 6 CEBAS-CSIC, Department of Soil and Water Conservation, Campus Universitario de Espinardo, 30100, Murcia, Spain \\ 7 Laboratory of Environmental Microbiology, Institute of Microbiology of the CAS, Vídeňská 1083, Praha 4 14220, Czech Republic
}

\section{ARTICLE INFO}

Article history:

Received November 16, 2019

Revised March 11, 2020

Accepted May 11, 2020

\section{Keywords:}

Tropical rainforest

Enzyme activity

Microbial community composition

Microbial biomass

Plant richness

\begin{abstract}
A B S T R A C T
The impact of forest microhabitats on physiochemical properties of the soil and that of microbial communities on tropical soils remain poorly understood. To elucidate the effect of tropical forest stand on leaf litter and soil microbial communities, we studied enzyme activities, microbial biomass, and diversity in three distinct microhabitats in terms of plant richness, diameter at breast height (DBH), and physiochemical properties of soil and litter, each associated with a different Vanilla sp. In the soil, positive correlations were found between electrical conductivity (EC) and total organic carbon (TOC) with phosphatase activity, and between nitrogen (N) and water-soluble carbon (WSC) content with urease activity (UA). In the litter, the water content was positively correlated with bacterial and fungal biomass, and $\mathrm{N}$ and WSC contents were positively correlated with fungal biomass. Positive correlations were found between plant richness and UA in the soil, plant richness and fungal biomass in the soil and litter, and DBH and fungal biomass in the litter. Amplicon sequencing revealed differences between microhabitats in the relative abundance of some fungal and bacterial taxa and in the bacterial community composition of both litter and soil. Bacterial richness and diversity were different between microhabitats, and, in litter samples, they were negatively correlated with $\mathrm{DBH}$ and plant richness, respectively. By contrast, none of the soil and litter physiochemical properties were significantly correlated with microbial diversity. Our results show that significant shifts in enzyme activity, microbial biomass, and diversity in the microhabitats were driven by key abiotic and biotic factors depending on the soil or litter sample type.
\end{abstract}

(c) Higher Education Press 2020

\footnotetext{
* Corresponding author

E-mail address: frank.solano.campos@una.ac.cr (F. Solano-Campos)
} 


\section{Introduction}

The microbial community of the soil is strongly linked to soil fertility through nutrient cycling (Bradford et al., 2016; Luo et al., 2016; Iwaoka et al., 2018; Ochoa-Hueso et al., 2018), and considerable efforts have been made to understand factors governing the microbial community composition and diversity of the soil (Bastida et al., 2016; Ramirez et al., 2017; Delgado-Baquerizo et al., 2018b). Several studies have shown bidirectional plant and microbial feedback, indicating that plants shape the diversity and composition of soil microbial communities through changes in soil temperature, moisture, physical structure, litter quality, and root exudates (Hartmann et al., 2009; Haichar et al., 2014; Hortal et al., 2017). In turn, soil microbial communities influence the structure of the plant community by altering plant performance and functional traits that affect ecosystem functioning (i.e., nutrient cycles and productivity) (Bardgett et al., 2014; Lozano et al., 2017). However, plant-microbial relationships, in addition to the microhabitat context, that may influence the composition and diversity of soil microbial communities (Burns et al., 2015; Prober et al., 2015; Štursova et al., 2016; Van Nuland et al., 2016; Si et al., 2018; Wu et al., 2019) remain poorly understood in tropical ecosystems (John et al., 2007; McCarthy-Neumann and Kobe, 2010; Liu et al., 2012; Waring, 2013).

Costa Rica possesses some of the most biodiverse areas on Earth, but information on the diversity and composition of the soil and leaf litter microbiome is scarce. In recent years, some studies have focused on soil microbial communities in Costa Rica using genomic approaches, and most of these were centered on characterization of fungal communities (Nemergut et al., 2010; Leff et al., 2012; Kivlin and Hawkes, 2016; Schilling et al., 2016; Waring et al., 2016; Xiong et al., 2016; Looby and Treseder, 2018; McGee et al., 2018). An information gap is evident regarding the microbial ecology of leaf litter and soil associated with both commercial and noncommercial wild Vanilla species. The importance of the Vanilla genus lies primarily in its commercial species $V$. planifolia, $V$. $\times$ tahitensis and $V$. pompona, which are the natural providers of vanillyl compounds used by the food and perfume industries (Korthou and Verpoorte, 2007; Ranadive, 2011; Maruenda et al., 2013). In Costa Rica, the genetic pool of Vanilla represents more than $10 \%$ of its diversity worldwide (Azofeifa-Bolaños et al., 2017; Karremans and Lehmann 2018). Despite the economic importance of V. planifolia, little attention has been given to Vanilla crop wild relatives, characterized by small, dispersed, and genetically distinct populations with low seed viability and complex inter-specific relationships within their natural habitats (Alomia et al., 2017; Azofeifa-Bolaños et al., 2018). Characterization of native forest soil and leaf litter microbial communities is an essential first step in the conservation of Vanilla spp. endangered genetic resources and the improvement of crop management strategies in ex situ and in situ production systems (Watteyn et al., 2020).
To fill the lack of information on plant-microbe interactions in the tropical rainforest, we studied the composition, diversity, biomass, and activity of microbial communities inhabiting the leaf litter and soil near three wild Vanilla species growing in microhabitats with distinct abiotic (i.e., soil moisture) and biotic (i.e., forest stand composition) properties. Given the relatively lower biomass of Vanilla spp. plants compared with other plants, we hypothesize that the forest stand, through direct (i.e., plant richness and litter properties) and indirect (i.e., shadow zones, soil properties, etc.) factors, will shape the litter and soil microbial communities associated with different Vanilla spp.

\section{Materials and methods}

\subsection{Study site and experimental design}

This study was performed at Piro Biological Station, Golfito, Puntarenas, Costa Rica (coordinates 8²4'4.4634" N, $\left.83^{\circ} 20^{\prime} 35.268^{\prime \prime} \mathrm{W}\right)$. A data set of georeferenced presence locations of Vanilla species was created from forest inventories that have been taken in Costa Rica since 2012 (Azofeifa-Bolaños et al., 2014, 2017). Recently, the use of ensemble species distribution models (SDMs) provided maps for the conservation and sustainable cultivation of four wild Vanilla species (Watteyn et al., 2020). Based on this data set and accurate SDMs focusing on the Osa Biological Corridor, only Piro Biological Station contained more than two populations of Vanilla crop wild relatives within the same land surface area (less than $5000 \mathrm{~m}^{2}$ ).

The climate of the study area is highly humid: type Af according to the Köppen-Geiger classification. The mean annual temperature and precipitation are $26.9^{\circ} \mathrm{C}$ and 4140 $\mathrm{mm}$, respectively, and the average elevation of the study area is $57 \mathrm{~m}$ above sea level. The soil is a Chromic Luvisol, according to the Food and Agriculture Organization (FAO) of the United Nations Educational, Scientific and Cultural Organization (UNESCO) Soil Map of the World (IUSS Working Group WRB, 2015). The dominant soil in the area has a $\mathrm{pH}$ of 4.39 , organic matter content of $3.02 \%$, and nitrogen content of $1.07 \%$, and the texture is sandy clay.

A study area of $2500 \mathrm{~m}^{2}$ of tropical rainforest was selected that contained three different Vanilla species belonging to the aromatic clade. The plant community in this area was dominated by Vochysia allenii (Vochysiaceae). Vanilla species were identified by morphological traits and DNA barcoding (GenBank accession numbers MH730192-MH730200). Three Vanilla species were identified as $V$. pompona (V1), V. odorata (V2) and V. sp. (V3). We distinguished three microhabitats with distinct traits consisting of abiotic (soil moisture and light) and biotic (plant richness and diameter at breast height) properties, each harboring a single Vanilla sp. A total of nine plots of $225 \mathrm{~m}^{2}$ each were selected: three plots contained V1 exclusively, three plots contained V2 exclusively, and the remaining three plots contained $\mathrm{V} 3$ exclusively. Thus, a total of nine plots were set up according to an 
experimental design with one factor (Vanilla presence) and three levels (Vanilla species), in triplicate $(n=3)$.

Plant richness and the average diameter at breast height $(\mathrm{DBH}$; at $1.3 \mathrm{~m})$ in each plot were determined. All the plant species with $\mathrm{DBH}>5 \mathrm{~cm}$ were measured and identified. Six bulk soil samples (0-10 cm depth) and litter samples (surface $0-5 \mathrm{~cm}$ litter layer) were collected in each plot in the proximity $(50 \mathrm{~cm})$ of each Vanilla sp. A composite soil and litter sample was obtained by thoroughly mixing the six samples per plot. Large woody litter, such as branches, was removed from the soil samples, and the soil was air-dried and sieved $(2 \mathrm{~mm}$ mesh). The litter was air-dried and ground to powder. Samples were stored at $4^{\circ} \mathrm{C}$ for analysis of chemical properties, enzyme activities, and phospholipid fatty acids (PLFAs) and at $-20^{\circ} \mathrm{C}$ for genomic analyses.

\subsection{Physiochemical analysis and enzyme activities}

Electrical conductivity and $\mathrm{pH}$ were measured in a 1:5 (w:v) aqueous extract using a conductivity meter and $\mathrm{pH}$ meter (Crison Mod. 2001, Barcelona, Spain), respectively. The total nitrogen content $(\mathrm{N})$ and total organic carbon (TOC) were determined using an Elemental Analyzer (C/N Flash EA 1112 Series-Leco Truspec, Thermo Scientific, MI, USA). Aqueous extracts of soil were prepared with deionized water (1:5, w:v) by shaking for $2 \mathrm{~h}$, followed by centrifugation at $13000 \mathrm{r} \mathrm{min}^{-1}$ for 15 min and filtration. Analysis of the $\mathrm{C}$ (WSC) and N (WSN) content in these extracts was performed in an analyzer for liquid samples (Multi N/C 3100, Analytik Jena). The percentage moisture content of the soil and litter samples was measured by oven-drying at $60^{\circ} \mathrm{C}$ until a constant weight was reached.

Urease activity ( $1 \mathrm{~g}$ soil samples and $300 \mathrm{mg}$ litter samples) was determined as the amount of $\mathrm{NH}_{4}{ }^{+}$released in the hydrolytic reaction using urea as substrate and borate buffer ( $\mathrm{pH} 10)$ (Kandeler and Gerber, 1988). The activities of alkaline phosphatase and $\beta$-glucosidase were determined according to Tabatabai and Bremner (1969) and Eivazi and Tabatabai (1977), respectively, with $0.5 \mathrm{~g}$ of soil or $100 \mathrm{mg}$ of litter. Polyphenol oxidase activity was determined by the method of Allison and Jastrow (2006), using pyrogallol as substrate with $0.5 \mathrm{~g}$ of soil and $100 \mathrm{mg}$ of litter.

\subsection{Phospholipid fatty acid analysis}

Phospholipids were extracted from $6 \mathrm{~g}$ of soil and $300 \mathrm{mg}$ of litter by chloroform-methanol extraction as described by Bligh and Dyer (1959), fractionated, and quantified as described by Frostegård et al. (1993). The phospholipids were transformed into fatty acid methyl esters by alkaline methanolysis (Frostegård et al., 1993). The bacterial biomass was represented by the following fatty acids: i15:0, a15:0, 15:0,

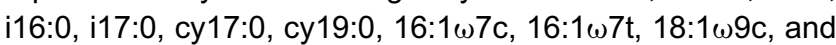

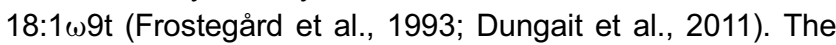
fatty acid 18:2u6 was used as an indicator of fungal biomass (Brant et al., 2006; Rinnan and Bååth, 2009). The representative Gram-positive fatty acids were i15:0, a15:0, i16:0, and i17:0. The fatty acids used to represent Gram-negative

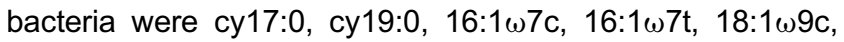

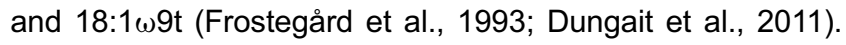
Actinobacterial representative fatty acids were $10 \mathrm{Me} 16: 0$ and 10Me18:0 (Ondoño et al., 2014).

\subsection{DNA extraction and metabarcoding analysis}

DNA was extracted from $500 \mathrm{mg}$ of freeze-dried soil sample and from $400 \mathrm{mg}$ of freeze-dried litter sample using the Fast DNA Spin Kit for soil and a FastPrep Instrument (MP Biomedicals, Santa Ana, CA, USA). The V4 region of bacterial 16S rRNA (rRNA) was amplified using the barcoded primers 515F and 806R as described previously (Caporaso et al., 2012). PCR amplification of the fungal ITS2 region from DNA was performed using barcoded gITS7 and ITS4 (Ihrmark et al., 2012) in three PCR reactions per sample, as described previously (Žifčáková et al., 2016). PCR products were cleaned using a MinElute Kit (Qiagen, Hilden, Germany) and their concentrations measured by Qubit fluorometer (Thermo Fisher Scientific). After preparation of libraries, sequencing of fungal and bacterial amplicons was performed on Illumina MiSeq. The pipeline seed2 was used for amplicon sequencing data pre-processing and diversity calculations (Větrovský et al., 2018). Briefly, pair-end reads were merged using fastq-join (Aronesty, 2013). Whole amplicons were processed for bacterial 16S, whereas the internal transcribed spacer 2 (ITS2) region was extracted using its Extractor 1.0.8 before processing. Chimeric sequences were detected using Usearch 7.0.1090 (Edgar, 2013) and deleted, and sequences were clustered using uparse implemented within Usearch, at a $97 \%$ similarity level. Consensus sequences were constructed for each cluster, and the closest hits at the genus or species level were identified using blastn against the Ribosomal Database Project (Cole et al., 2014) for bacteria or unite (Koljalg et al., 2014) for fungi. Sequences identified as nonbacterial or non-fungal were discarded. Low-abundance operational taxonomic units (OTUs) with fewer than $1 \%$ of the sequences for fungal analyses or fewer than $0.5 \%$ for bacterial analyses were filtered. The Shannon-Wiener index of diversity was calculated for bacterial diversity based on $16 \mathrm{~S}$ rRNA gene sequencing or for fungal diversity based on ITS sequencing. Sequencing data used in this study are archived at the MG-RAST public database (project ID mgp86094).

\subsection{Data analysis}

The normality and the homogeneity of variances were tested by the Ryan-Joiner and Levene tests, respectively. For soil and litter, the physiochemical parameters, PLFA content, and enzyme activity data were analyzed by one-way ANOVA followed by post-hoc analyses using Tukey's significant difference test using Minitab 17.1 (Minitab Inc., State College, PA, USA). Differences at $p<0.05$ were regarded as statistically significant. All results are reported as means \pm standard deviations. Principal coordinates analysis (PCoA) on BrayCurtis distances was used to visualize differences in the 
microbial community composition. PCoA was performed using PAST 3.22 (Hammer et al., 2001). Effects of distinct microhabitats on bacterial and fungal community compositions were assessed using non-parametric permutational multivariate analysis of variance (PERMANOVA) (Anderson, 2001). The analysis of multivariate homogeneity of group dispersions and the PERMANOVA on Bray-Curtis distances were performed with the betadisper and adonis functions of the vegan package (Oksanen et al., 2019) in $R$ ( $R$ Core Team, 2019). Pearson correlations among the physiochemical parameters, enzyme activities, plant richness and $\mathrm{DBH}$, PLFA content (an indicator of microbial biomass), microbial diversity, and richness in the litter and soil samples were determined using Minitab 17.1 (Minitab Inc.).

\section{Results}

\subsection{Plant richness and $\mathrm{DBH}$}

The sampling area was a complex and multi-layered secondary forest dominated by large tree species of the families Vochysiaceae, Melastomataceae, and Malpighiaceae. Despite the close proximity of the three wild Vanilla species that were sampled, plant richness differed between sites (Table 1). Environmental conditions and $\mathrm{DBH}$ in each microhabitat were also different. The canopy of V3 was dominated by Vochysia allenii trees, which also had the highest $\mathrm{DBH}$ values in the sampling area. Site V2 was predominated by medium-sized trees of Henriettea succosa and Miconia argentea. V1 was dominated by Byrsonima crassifolia trees, with randomly distributed gaps allowing a higher irradiance below the canopy and lower soil moisture compared with the other sites. The plant richness was greatest at site V3, followed by V1 and V2, and V3 also had the highest litter moisture content.

\subsection{Physiochemical parameters}

There were no significant differences among the sites in $\mathrm{pH}$, total C, total N, TOC, or WSN in the litter samples (Table 2). However, the electrical conductivity was significantly higher for the V3 samples compared with that of V1 and V2 samples, and the WSC was significantly higher for V2 than for V1 $(p<0.05)$. In addition, the litter moisture content was significantly higher in V3 compared with that of V1 (Table 2).

For the soil samples, no significant differences were found among the sites for $\mathrm{pH}$, TOC, WSN, or moisture (Table 2). The electrical conductivity was significantly lower in the soil of V2 than in that of $\mathrm{V} 1$ and $\mathrm{V} 3$. Total $\mathrm{N}, \mathrm{C}$, and WSC were highest in the V3 samples $(p<0.05)$ (Table 2$)$.

\subsection{Enzyme activities}

The activities of $\beta$-glucosidase and urease in the litter samples did not differ significantly between sites (Table 3). However, the phosphatase activity of V1 litter samples was significantly higher compared with that in V3 samples, and the phenoloxidase activity of V2 was significantly higher than that in V3 $(p<0.05)$.

In the soil samples, no significant differences arose between sites for the activities of $\beta$-glucosidase and phenoloxidase (Table 3 ). We observed significantly lower phosphatase activity in V2 soil compared with that of the other sites; however, the soil samples from site V3 had significantly greater urease activity than those of $\mathrm{V} 1$ and $\mathrm{V} 2(p<0.05)$.

\subsection{PLFA analysis}

In litter samples, the PLFA content representative of fungal content and bacteria, including gram positive and gram negative, were significantly higher in V2 and V3 compared with V1 $(p<0.05)$. The fungal/bacterial PLFA ratio was significantly higher in V3 samples than in V1 and V2 samples $(p<0.05)$. Furthermore, Actinobacteria were significantly more abundant in litter from the microhabitat of V3 compared with that of $\mathrm{V} 1(p<0.05)$ (Table 4).

For soil samples, the bacterial PLFA content including gram-positive samples and the fungal PLFA content were significantly higher in V2 and V3 sites, compared with those of the V1 site $(p<0.05)$. The Gram-negative PLFA content was greater in $\mathrm{V} 2$ than in $\mathrm{V} 1$, and the fungal/bacterial PLFA ratio was significantly higher in V3 compared with that of V1 and V2 $(p<0.05)$. The Gram-positive/negative ratio did not differ significantly among sites (Table 4).

\subsection{Correlation analysis}

3.5.1 Effect of litter and soil physiochemical properties on microbial activities, biomass, and diversity

Neither bacterial and fungal diversity (the Shannon-Wiener index) nor phenol-oxidase activity was significantly correlated with any of the chemical or physiochemical properties that were assessed in the soil and litter samples $(p \geqslant 0.05)$ (Tables S1 and S2).

In litter samples, bacterial richness had a significant negative correlation with EC and litter moisture $(p<0.05)$. Furthermore, bacterial PLFA content was positively correlated with litter moisture, and fungal PLFA content had a significant positive correlation both with EC and litter moisture $(p<0.05)$ (Table S1).

In soil samples, alkaline phosphatase activity was positively correlated with both EC and TOC $(p<0.05)$. Similarly, N and WSC contents were positively correlated with urease enzyme activity $(p<0.05)$. Fungal PLFA content was also positively correlated with N and WSC $(p<0.05)$ (Table S2).

3.5.2 Effect of plant richness and $\mathrm{DBH}$ on microbial activities, biomass, and diversity

In litter samples, plant richness had a significant positive correlation with fungal biomass and a significant negative correlation with WSC, phosphatase activity, phenol-oxidase activity, and bacterial diversity $(p<0.05)$. $\mathrm{DBH}$ was positively 
Table 1 Plant richness and diameter at breast height ( $\mathrm{DBH})$ of each site.

\begin{tabular}{|c|c|c|c|}
\hline \multirow[t]{2}{*}{ Site } & \multicolumn{2}{|l|}{ Plant richness } & \multirow[t]{2}{*}{$\mathrm{DBH}(\mathrm{cm})$} \\
\hline & Species & Family & \\
\hline \multirow[t]{8}{*}{$\mathrm{V}^{\dagger}$} & Garcinia sp. & Clusiaceae & $40.75^{\mathrm{a}} \pm 17.95^{\S}$ \\
\hline & Tetracera sp. & Dilleniaceae & \\
\hline & Doliocarpus multiflorus Standl. & Dilleniaceae & \\
\hline & Lacistema aggregatum (P.J. Bergius) Rusby & Lacistemataceae & \\
\hline & Byrsonima crassifolia (L.) Kunth & Malpighiaceae & \\
\hline & Henriettea succosa (Aubl.) DC. & Melastomataceae & \\
\hline & Casearia arborea (Rich.) Urb. & Salicaceae & \\
\hline & Vochysia allenii Standl. \& L.O. Williams & Vochysiaceae & \\
\hline \multirow[t]{6}{*}{ V2 } & Clusia sp. & Clusiaceae & $55.25^{\mathrm{ab}} \pm 32.57$ \\
\hline & Davilla nitida (Vahl) Kubitzki & Dilleniaceae & \\
\hline & Byrsonima crassifolia (L.) Kunth & Malpighiaceae & \\
\hline & Henriettea succosa (Aubl.) DC. & Melastomataceae & \\
\hline & Miconia argentea (Sw.) DC. & Melastomataceae & \\
\hline & Alibertia edulis (Rich.) A. Rich. & Rubiaceae & \\
\hline \multirow[t]{15}{*}{ V3 } & Annona amazonica & Annonaceae & $90.33^{\mathrm{b}} \pm 21.46$ \\
\hline & Davilla nitida (Vahl) Kubitzki & Dilleniaceae & \\
\hline & Inga sp. & Fabaceae & \\
\hline & Vantanea barbourii Standl. & Humiriaceae & \\
\hline & Nectandra umbrosa (Kunth) Mez & Lauraceae & \\
\hline & Ocotea sp. & Lauraceae & \\
\hline & Henriettea succosa (Aubl.) DC. & Melastomataceae & \\
\hline & Erblichia odorata Seem. & Passifloraceae & \\
\hline & Piper sp. & Piperaceae & \\
\hline & Alibertia edulis (Rich.) A. Rich. & Rubiaceae & \\
\hline & Arachnothryx sp. & Rubiaceae & \\
\hline & Chiococca belizensis Lundell & Rubiaceae & \\
\hline & Posoqueria sp. & Rubiaceae & \\
\hline & Casearia sp. & Salicaceae & \\
\hline & Vochysia allenii Standl. \& L.O. Williams & Vochysiaceae & \\
\hline
\end{tabular}

${ }^{\dagger} \mathrm{V} 1=V$. pompona; $\mathrm{V} 2=\mathrm{V}$. odorata; $\mathrm{V} 3=V$. sp. ${ }^{\ddagger}$ Different letters indicate a significant difference $(p<0.05) .{ }^{\S}$ Values are means \pm standard deviations.

correlated with fungal biomass but showed an opposite trend with bacterial richness $(p<0.05)$ (Table S1).

In soil samples, plant richness had a significant positive correlation with $\mathrm{C}, \mathrm{WSC}$, urease activity, and fungal PLFA content $(p<0.05)$ (Table S2).

\subsection{Diversity and composition of the microbial community}

The fungal community from the litter of all microhabitats was dominated by the classes Agaricomycetes (up to $52.38 \%$ of the sequences) and Sordariomycetes (up to $39.82 \%$ ) (Fig. S1A). Class Agaricomycetes was more abundant in V3 samples compared with those of V2 and V1 (52.38\% in V3 vs. $36.55 \%$ in $\mathrm{V} 2$ and $21.37 \%$ in $\mathrm{V} 1$ ), while the abundance of Sordariomycetes followed a different trend $(39.82 \%$ in V2 vs. $16.06 \%$ in V1 and $9.46 \%$ in V3) (Fig. S1A). At the genus level, Crinipellis (up to $18.87 \%$ ), Mycena (up to $16.82 \%$ ), Castane- diella (up to $15.38 \%$ ), and Calonectria (up to $12.18 \%$ ) were the most abundant genera (Fig. 1A).

We found that Proteobacteria (up to $92.27 \%$ of the sequences), Verrucomicrobia (up to $10.41 \%$ ) and Acidobacteria (up to $8.17 \%$ ) were the most abundantly represented phyla in the litter samples (Fig. S1B). Both Acidobacteria and Verrucomicrobia were more abundant in V3 samples $(8.17 \%$ and $10.41 \%$, respectively) than in $\mathrm{V} 1(1.43 \%$ and $6.30 \%$, respectively) and V2 $(0.00 \%$ and $5.29 \%$, respectively), whereas Proteobacteria was more abundant in V1 and V2 (90.71\% and $92.27 \%$, respectively) litter samples than in V3 (80.15\%) (Fig. S1B). The most abundant genera were Pseudolabrys (up to $32.69 \%$ ) and Bradyrhizobium (up to $25.87 \%)$. Pseudolabrys was more abundant in V3 $(32.69 \%)$ than in V1 (25.09\%) and V2 (24.02\%) (Fig. 1B).

In soil samples, Eurotiomycetes (up to $27.87 \%$ ) and Sordariomycetes (up to $17.78 \%$ ) were the most abundant 
Table 2 Litter and soil chemical and physical analyses.

\begin{tabular}{|c|c|c|c|c|c|c|}
\hline \multirow[t]{2}{*}{ Parameter } & \multicolumn{3}{|l|}{ Litter } & \multicolumn{3}{|l|}{ Soil } \\
\hline & $\mathrm{V} 1^{\ddagger}$ & V2 & V3 & V1 & V2 & V3 \\
\hline $\mathrm{pH}$ & $\begin{array}{l}6.89^{\mathrm{a}}{ }^{\#} \\
\pm 0.10^{\#}\end{array}$ & $\begin{array}{l}6.65^{a} \\
\pm 0.10\end{array}$ & $\begin{array}{l}6.70^{a} \\
\pm 0.20\end{array}$ & $\begin{array}{l}5.80^{a} \\
\pm 0.15\end{array}$ & $\begin{array}{l}5.80^{\mathrm{a}} \\
\pm 0.06\end{array}$ & $\begin{array}{l}5.58^{a} \\
\pm 0.01\end{array}$ \\
\hline Electrical conductivity $\left(\mu \mathrm{S} \mathrm{cm}{ }^{-1}\right)$ & $\begin{array}{l}72.30^{\mathrm{b}} \\
\pm 1.57\end{array}$ & $\begin{array}{l}70.43^{b} \\
\pm 5.87\end{array}$ & $\begin{array}{l}85.83^{a} \\
\pm 1.46\end{array}$ & $\begin{array}{l}88.50^{\mathrm{a}} \\
\pm 0.10\end{array}$ & $\begin{array}{l}64.47^{\mathrm{b}} \\
\pm 0.90\end{array}$ & $\begin{array}{l}102.80^{\mathrm{a}} \\
\pm 10.17\end{array}$ \\
\hline Total N (g 100g $\left.{ }^{-1}\right)$ & $\begin{array}{l}1.04^{a} \\
\pm 0.06\end{array}$ & $\begin{array}{l}0.96^{a} \\
\pm 0.10\end{array}$ & $\begin{array}{l}0.88^{a} \\
\pm 0.15\end{array}$ & $\begin{array}{l}0.38^{\mathrm{b}} \\
\pm 0.03\end{array}$ & $\begin{array}{l}0.39^{\mathrm{ab}} \\
\pm 0.02\end{array}$ & $\begin{array}{l}0.46^{\mathrm{a}} \\
\pm 0.03\end{array}$ \\
\hline Total C $\left(\mathrm{g} 100 \mathrm{~g}^{-1}\right)$ & $\begin{array}{l}29.83^{a} \\
\pm 3.78\end{array}$ & $\begin{array}{l}31.75^{\mathrm{a}} \\
\pm 3.14\end{array}$ & $\begin{array}{l}24.47^{a} \\
\pm 4.83\end{array}$ & $\begin{array}{l}5.45^{\mathrm{ab}} \\
\pm 0.22\end{array}$ & $\begin{array}{l}4.94^{\mathrm{b}} \\
\pm 0.14\end{array}$ & $\begin{array}{l}5.95^{\mathrm{a}} \\
\pm 0.63\end{array}$ \\
\hline $\operatorname{TOC}^{\dagger}\left(g_{100 g^{-1}}\right)$ & $\begin{array}{l}30.07^{\mathrm{a}} \\
\pm 3.41\end{array}$ & $\begin{array}{l}31.70^{a} \\
\pm 3.12\end{array}$ & $\begin{array}{l}24.18^{a} \\
\pm 5.06\end{array}$ & $\begin{array}{l}5.14^{a} \\
\pm 0.29\end{array}$ & $\begin{array}{l}4.67^{a} \\
\pm 0.45\end{array}$ & $\begin{array}{l}5.63^{\mathrm{a}} \\
\pm 0.80\end{array}$ \\
\hline WSC $\left(\mathrm{mg} \mathrm{kg}^{-1}\right)$ & $\begin{array}{l}2273.23^{b} \\
\pm 155.43\end{array}$ & $\begin{array}{l}2836.99^{a} \\
\pm 278.12\end{array}$ & $\begin{array}{l}2476.37^{\mathrm{ab}} \\
\pm 60.05\end{array}$ & $\begin{array}{l}325.37^{b} \\
\pm 65.52\end{array}$ & $\begin{array}{l}348.38^{b} \\
\pm 4.00\end{array}$ & $\begin{array}{l}464.06^{a} \\
\pm 36.40\end{array}$ \\
\hline WSN (mg kg $\left.{ }^{-1}\right)$ & $\begin{array}{l}120.17^{\mathrm{a}} \\
\pm 25.04\end{array}$ & $\begin{array}{l}123.31^{\mathrm{a}} \\
\pm 21.09\end{array}$ & $\begin{array}{l}131.08^{\mathrm{a}} \\
\pm 16.58\end{array}$ & $\begin{array}{l}17.14^{\mathrm{a}} \\
\pm 4.34\end{array}$ & $\begin{array}{l}14.02^{\mathrm{a}} \\
\pm 0.89\end{array}$ & $\begin{array}{l}20.69^{\mathrm{a}} \\
\pm 2.86\end{array}$ \\
\hline Moisture (\%) & $\begin{array}{l}41.36^{\mathrm{b}} \\
\pm 1.15\end{array}$ & $\begin{array}{l}50.35^{\mathrm{ab}} \\
\pm 9.50\end{array}$ & $\begin{array}{l}58.67^{a} \\
\pm 3.16\end{array}$ & $\begin{array}{l}6.43^{\mathrm{a}} \\
\pm 2.16\end{array}$ & $\begin{array}{l}3.27^{\mathrm{a}} \\
\pm 0.58\end{array}$ & $\begin{array}{l}5.00^{\mathrm{a}} \\
\pm 1.67\end{array}$ \\
\hline
\end{tabular}

${ }^{\dagger}$ TOC (total organic carbon); WSC (water-soluble C content); WSN (water-soluble $\mathrm{N}$ content). ${ }^{\ddagger} \mathrm{V} 1=\mathrm{V}$. pompona; V2 = V. odorata; V3 = V. sp. ${ }^{\S}$ Different letters within a specific row indicate a significant difference $(p<0.05$; Tukey HSD test). " Values are means \pm standard deviations of three replications.

Table 3 Enzyme activities in the litter and soil samples.

\begin{tabular}{|c|c|c|c|c|c|c|}
\hline \multirow[t]{2}{*}{ Enzyme } & \multicolumn{3}{|l|}{ Litter } & \multicolumn{3}{|l|}{ Soil } \\
\hline & $\overline{\mathrm{V} 1^{\dagger}}$ & V2 & V3 & $\overline{\mathrm{V} 1}$ & V2 & V3 \\
\hline $\bar{\beta}$-Glucosidase $\left(\mu \mathrm{mol} \mathrm{PNP} \mathrm{g}^{-1} \mathrm{~h}^{-1}\right)$ & $\begin{array}{l}2.08^{\text {ał }} \\
\pm 0.54^{\S}\end{array}$ & $\begin{array}{l}2.31^{a} \\
\pm 0.47\end{array}$ & $\begin{array}{l}1.87^{\mathrm{a}} \\
\pm 0.44\end{array}$ & $\begin{array}{l}0.44^{a} \\
\pm 0.08\end{array}$ & $\begin{array}{l}0.42^{\mathrm{a}} \\
\pm 0.03\end{array}$ & $\begin{array}{l}0.51^{\mathrm{a}} \\
\pm 0.08\end{array}$ \\
\hline Alkaline phosphatase $\left(\mu \mathrm{mol}\right.$ PNP $\left.\mathrm{g}^{-1} \mathrm{~h}^{-1}\right)$ & $\begin{array}{l}27.11^{\mathrm{a}} \\
\pm 2.06\end{array}$ & $\begin{array}{l}24.20^{\mathrm{ab}} \\
\pm 2.24\end{array}$ & $\begin{array}{l}21.50^{\mathrm{b}} \\
\pm 1.92\end{array}$ & $\begin{array}{l}3.73^{\mathrm{a}} \\
\pm 0.51\end{array}$ & $\begin{array}{l}2.12^{\mathrm{b}} \\
\pm 0.08\end{array}$ & $\begin{array}{l}3.58^{\mathrm{a}} \\
\pm 0.30\end{array}$ \\
\hline Urease $\left(\mu \mathrm{mol} \mathrm{NH} \mathrm{H}_{3} \mathrm{~g}^{-1} \mathrm{~h}^{-1}\right)$ & $\begin{array}{l}1.97^{\mathrm{a}} \\
\pm 0.68\end{array}$ & $\begin{array}{l}1.45^{\mathrm{a}} \\
\pm 0.39)\end{array}$ & $\begin{array}{l}1.72^{\mathrm{a}} \\
\pm 0.25\end{array}$ & $\begin{array}{l}1.47^{\mathrm{b}} \\
\pm 0.10\end{array}$ & $\begin{array}{l}1.47^{\mathrm{b}} \\
\pm 0.10\end{array}$ & $\begin{array}{l}2.06^{a} \\
\pm 0.15\end{array}$ \\
\hline Phenol-oxidase ( $\mu$ mol pyrogallol g ${ }^{-1} \mathrm{~h}^{-1}$ ) & $\begin{array}{l}70.95^{\mathrm{ab}} \\
\pm 4.59\end{array}$ & $\begin{array}{l}84.50^{\mathrm{a}} \\
\pm 8.32\end{array}$ & $\begin{array}{l}59.65^{\mathrm{b}} \\
\pm 1.47\end{array}$ & $\begin{array}{l}9.63^{\mathrm{a}} \\
\pm 1.07\end{array}$ & $\begin{array}{l}7.43^{\mathrm{a}} \\
\pm 2.29\end{array}$ & $\begin{array}{r}10.0^{\mathrm{a}} \\
\pm 2.29\end{array}$ \\
\hline
\end{tabular}

${ }^{\dagger} \mathrm{V} 1=\mathrm{V}$. pompona; $\mathrm{V} 2=\mathrm{V}$. odorata; $\mathrm{V} 3=\mathrm{V} . \mathrm{sp} .{ }^{\ddagger}$ Different letters within a specific row indicate a significant difference $(p<0.05 ;$ Tukey HSD test).

$\S$ Values are means \pm standard deviations of three replications.

fungal classes in all microhabitats (Fig. S1A). The class Sordariomycetes was more abundant in V1 $(17.78 \%)$ compared with that in V2 and V3 $(10.06 \%$ and $11.39 \%$, respectively) (Fig. S1A). Diaporthe (up to $11.76 \%$ ) was the most abundant fungal genus among all sites (Fig. 1A).

Proteobacteria (up to $47.28 \%$ of the sequences), Verrucomicrobia (up to $23.93 \%$ ) and Acidobacteria (up to $21.70 \%$ ) were the most abundant phyla in all sites (Fig. S1B). The class Gammaproteobacteria $(0.68 \%$ of the sequences) and the phylum Cyanobacteria $(0.76 \%$ of the sequences) were found only in V1 (Fig. S1B). Pseudolabrys (up to 16.95\%), Candidatus Solibacter (up to $5.78 \%$ ) and Bradyrhizobium $(5.17 \%)$ were the most abundant bacterial genera (Fig. 1B).

For fungal diversity, the richness and Shannon-Wiener index did not vary significantly between the soil samples $(p \geqslant 0.05)$ or litter samples $(p \geqslant 0.05)$. For bacterial diversity, the richness and Shannon-Wiener index in soil and litter of the $\mathrm{V} 1$ microhabitat were significantly higher than those of V3 $(p<0.05)$ (Table 5).

A PCoA analysis of Bray-Curtis distances of bacterial and fungal communities assessed through 16S rRNA and ITS sequencing revealed clear differences in the composition of the microbial communities. The composition of the fungal community (Table S3) was not significantly different between soil samples (PERMANOVA $p>0.05$ ) (Fig. 2A), but it was significantly different between litter samples (PERMANOVA $p=0.0033$ ) (Fig. 2B). Marasmius and Rhinocladiella were found only in the litter from V1, where Crinipellis and Mycena were absent. The genera Calonectria, Parapleurotheciopsis, and Sarcodon were unique to V2 litter. Aspicilia, Banhegyia, and Veronaeopsis were found exclusively in V3 litter, whereas Castanediella, Corniculariella, Ochroconis, and Uncobasi- 
Table 4 Mean values ( $\mathrm{nmol} \mathrm{g}{ }^{-1}$ ) and standard deviation of bacterial, fungal, Gram+, Gram- and actinobacterial phospholipid fatty acid (PLFA) contents in litter and soil samples.

\begin{tabular}{|c|c|c|c|c|c|c|}
\hline \multirow[t]{2}{*}{ PLFA biomarkers } & \multicolumn{3}{|l|}{ Litter } & \multicolumn{3}{|l|}{ Soil } \\
\hline & $\overline{\mathrm{V} 1^{\dagger}}$ & V2 & V3 & $\overline{\mathrm{V} 1}$ & V2 & V3 \\
\hline Bacteria & $22.87^{\mathrm{bf}} \pm 5.55^{\S}$ & $56.66^{\mathrm{a}} \pm 2.42$ & $67.52^{\mathrm{a}} \pm 4.56$ & $3.88^{b} \pm 0.51$ & $6.47^{\mathrm{a}} \pm 0.50$ & $5.50^{\mathrm{a}} \pm 0.14$ \\
\hline Fungi & $7.51^{\mathrm{c}} \pm 0.89$ & $16.93^{\mathrm{b}} \pm 1.93$ & $29.27^{a} \pm 1.63$ & $0.20^{\mathrm{c}} \pm 0.03$ & $0.34^{\mathrm{b}} \pm 0.04$ & $0.54^{\mathrm{a}} \pm 0.05$ \\
\hline Gram + & $16.02^{\mathrm{b}} \pm 2.75$ & $34.20^{\mathrm{a}} \pm 1.73$ & $40.92^{\mathrm{a}} \pm 3.62$ & $2.87^{\mathrm{b}} \pm 0.50$ & $4.89^{\mathrm{a}} \pm 0.12$ & $4.26^{\mathrm{a}} \pm 0.02$ \\
\hline Gram- & $11.85^{\mathrm{b}} \pm 2.85$ & $22.46^{a} \pm 1.80$ & $26.60^{\mathrm{a}} \pm 1.17$ & $0.97^{\mathrm{b}} \pm 0.17$ & $1.48^{\mathrm{a}} \pm 0.28$ & $1.24^{\mathrm{ab}} \pm 0.13$ \\
\hline Actinobacteria & $1.16^{\mathrm{b}} \pm 0.43$ & $1.42^{\mathrm{ab}} \pm 0.18$ & $2.07^{\mathrm{a}} \pm 0.38$ & $0.21^{\mathrm{a}} \pm 0.07$ & $0.29^{\mathrm{a}} \pm 0.01$ & $0.24^{\mathrm{a}} \pm 0.01$ \\
\hline Fungi/bacteria & $0.27^{b} \pm 0.02$ & $0.30^{\mathrm{b}} \pm 0.04$ & $0.43^{\mathrm{a}} \pm 0.03$ & $0.05^{\mathrm{b}} \pm 0.00$ & $0.05^{\mathrm{b}} \pm 0.00$ & $0.1_{ \pm 0.01}^{a}$ \\
\hline Gram+/Gram- & $1.37^{\mathrm{a}} \pm 0.11$ & $1.53^{\mathrm{a}} \pm 0.15$ & $1.54^{\mathrm{a}} \pm 0.10$ & $2.99^{\mathrm{a}} \pm 0.64$ & $3.37^{\mathrm{a}} \pm 0.60$ & $3.48^{\mathrm{a}} \pm 0.37$ \\
\hline
\end{tabular}

${ }^{\dagger} \mathrm{V} 1=\mathrm{V}$. pompona; $\mathrm{V} 2=\mathrm{V}$. odorata; $\mathrm{V} 3=\mathrm{V} . \mathrm{sp}$. ${ }^{\ddagger}$ Different letters within a specific row indicate a significant difference $(p<0.05 ;$ Tukey HSD test).

$\S$ Values are means \pm standard deviations of three replications.
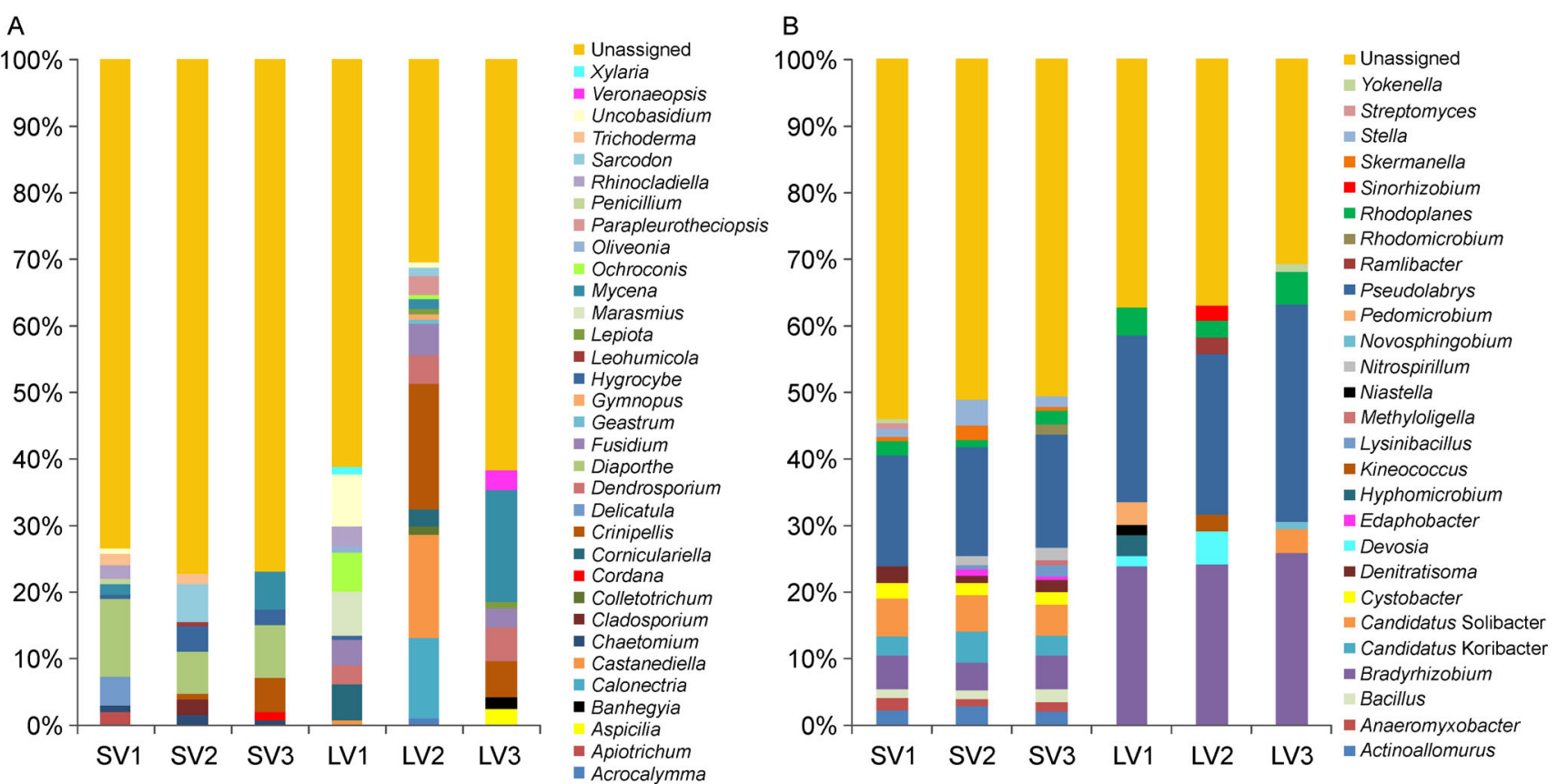

Fig. 1 Relative abundance of the fungal (A) and bacterial (B) communities at the genus level based on Illumina MiSeq sequencing of the fungal ITS2 region and the V4 region of the bacterial $16 \mathrm{~S}$ rRNA gene. The figures include taxa with $>1 \%$ (for fungi) and $>0.5 \%$ (for bacteria) mean relative abundance. SV1, SV2 and SV3 are the soil samples corresponding to V. pompona, V. odorata and V. sp., respectively. LV1, LV2 and LV3 are the respective litter samples corresponding to these Vanilla species. Data represent the mean of 3 replicate samples.

dium were absent from the litter at $\mathrm{V} 3$ (Fig. 2B). The bacterial community composition (Table S4) was significantly different between soil samples (PERMANOVA $p=0.0106)$ (Fig. 3A) and litter samples (PERMANOVA $p=0.0348$ ) (Fig. 3B). In soil samples, $\mathrm{V} 1$ samples were clearly different from those of $\mathrm{V} 2$ and V3. In V1, the genera Edaphobacter, Lysinibacillus, and Nitrospirillum were absent, but Streptomyces and Yokenella were unique. Methyloligella and Rhodomicrobium were only found in V3 (Fig. 3A). In litter samples, the genus Candidatus Solibacter was present only in litter samples from V3, from which Devosia was absent (Fig. 3B). The genera Hyphomicrobium and Pedomicrobium were detected only in $\mathrm{V} 1$, and Kineococcus, Ramlibacter, and Sinorhizobium only in V2.

\section{Discussion}

Our results demonstrate that the microbial activity, biomass, and community composition of litter and soil samples differed among the three microhabitats, and that these differences may be attributed to abiotic (i.e., litter moisture) and biotic (i.e., plant richness) differences among the sites.

4.1 Effect of physiochemical properties of soil and litter on microbial activities, biomass, and diversity

In this study, the soil from V1 and V3 microhabitats had the highest EC and alkaline phosphatase activity, and they were positively correlated. Similar results were reported by Lema- 
nowicz and Bartkowiak (2016), who found a positive correlation between phosphatase activity and EC in a salinized grassland habitat. EC may therefore impact the formation of the activity center and the molecular stability of extracellular enzymes (Lemanowicz and Bartkowiak, 2016; Singh, 2016). In addition, in these microhabitats, alkaline phosphatase and soil TOC were positively correlated with each other, as described in other studies (Saha et al., 2008; Lemanowicz, 2018; Zhang et al., 2018; Si et al., 2018). In tropical ecosystems, most phosphorus from the soil is adsorbed in recalcitrant minerals and organic compounds that decrease its availability for biological assimilation (Yao et al., 2018). Therefore, high phosphatase activity is very important because it plays a fundamental role in the transformation of phosphorus from organic matter in the soil into plant-available phosphate (Margalef et al., 2017).

Additionally, soil urease enzyme activity was positively correlated with nitrogen content and WSC, and this activity was higher in microhabitat V3. This is consistent with other studies that found a positive correlation between urease activity and nitrogen content (Xie et al., 2016; Zhang et al., 2016a; Guangming et al., 2017). This is likely due to the involvement of urease in soil nitrogen transformation, which decomposes urea into ammonia and carbon dioxide (Guangming et al., 2017; Tianzhu et al., 2017). Other studies also have determined a positive correlation between urease and WSC (Tianzhu et al., 2017; Liu et al., 2019). This may be explained by microbial stimulation caused by the higher amount of organic carbon (Liu et al., 2019). Together, these results suggest that microorganisms may regulate their enzyme expression depending on the physiochemical properties of the soil and litter (Smith et al., 2015; Cabugao et al., 2017; Prather et al., 2017; Mazzon et al., 2018).

Furthermore, the contents of both the bacterial and fungal PLFA in litter samples were positively correlated with litter moisture and presented higher values in V3 and V2 microhabitats compared with that of V1. Lange et al. (2014) determined that moisture content indirectly increases microbial biomass and therefore suggested that the moisture content holds a central position in the interplay between plant diversity, abiotic soil conditions, and microbial biomass. The soil from the V3 microhabitat had the highest $\mathrm{N}$ content, WSC, and fungal PLFA content, and these were positively correlated. As reported here, Wei et al. (2018) also found that the microbial biomass increased significantly by the addition of nitrogen in a Larix gmelinii plantation.

4.2 Effect of plant richness and DBH on microbial activities, biomass, and diversity

In litter samples, we observed that phenol-oxidase activity was lower when the plant richness was the highest. However,

Table 5 Fungal and bacterial alpha diversity measures in each microhabitat.

\begin{tabular}{|c|c|c|c|c|}
\hline \multirow[t]{2}{*}{ Microhabitat } & \multicolumn{2}{|l|}{ Fungi } & \multicolumn{2}{|l|}{ Bacteria } \\
\hline & Richness & Shannon-Wiener & Richness & Shannon-Wiener \\
\hline \multicolumn{5}{|l|}{ Litter } \\
\hline $\mathrm{V} 1^{\dagger}$ & $536.00 \pm 104.73^{a \neq \S}$ & $4.82 \pm 0.53^{\mathrm{a}}$ & $3105.67 \pm 79.98^{a}$ & $7.17 \pm 0.05^{\mathrm{a}}$ \\
\hline V2 & $545.00 \pm 31.18^{a}$ & $4.73 \pm 0.09^{a}$ & $2976.50 \pm 30.41^{a}$ & $7.07 \pm 0.09^{a}$ \\
\hline V3 & $545.00 \pm 47.76^{a}$ & $4.78 \pm 0.25^{a}$ & $2761.33 \pm 43.98^{\mathrm{b}}$ & $6.83 \pm 0.04^{b}$ \\
\hline \multicolumn{5}{|l|}{ Soil } \\
\hline V1 & $388.33 \pm 57.19^{a}$ & $4.54 \pm 0.14^{\mathrm{a}}$ & $2227.67 \pm 138.38^{a}$ & $6.45 \pm 0.09^{a}$ \\
\hline V2 & $426.33 \pm 60.38^{a}$ & $4.43 \pm 0.19^{a}$ & $2001.00 \pm 70.41^{a b}$ & $6.14 \pm 0.03^{\mathrm{ab}}$ \\
\hline V3 & $388.67 \pm 42.74^{a}$ & $4.33 \pm 0.14^{\mathrm{a}}$ & $1763.33 \pm 136.55^{\mathrm{b}}$ & $6.00 \pm 0.17^{\mathrm{b}}$ \\
\hline
\end{tabular}

${ }^{\dagger} \mathrm{V} 1=V$. pompona; $\mathrm{V} 2=\mathrm{V}$. odorata; $\mathrm{V} 3=\mathrm{V} . \mathrm{sp} .{ }^{\ddagger}$ Different letters for each measure and between each microhabitat in litter and soil indicate a significant difference $(p<0.05)$. ${ }^{\S}$ Values are means \pm standard deviations of three replications.

A

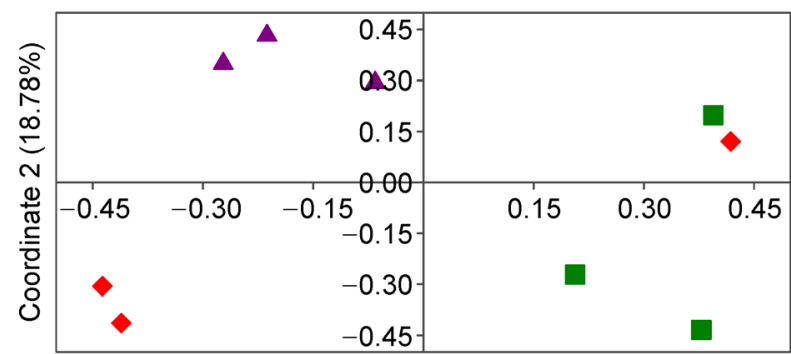

Coordinate $1(28.08 \%)$
B

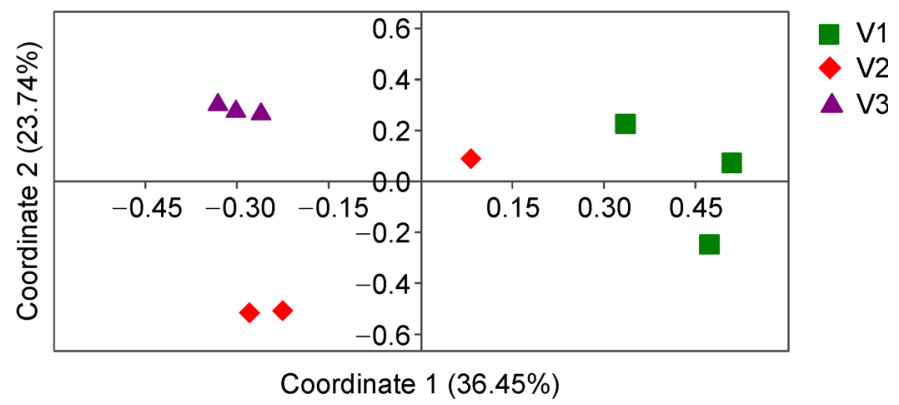

Fig. 2 Principal coordinates analysis ( $P C O A)$ based on a Bray-Curtis dissimilarity matrix of the fungal communities in soil (A) and litter (B) samples. OTUs $>1 \%$ in any of the soil samples and litter samples were included. V1, V2 and V3 correspond to $V$. pompona, V. odorata and $V$. sp., respectively. 
A

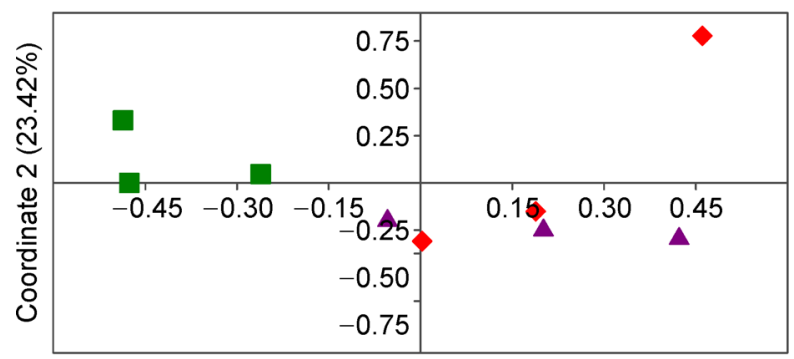

Coordinate $1(40.97 \%)$
B

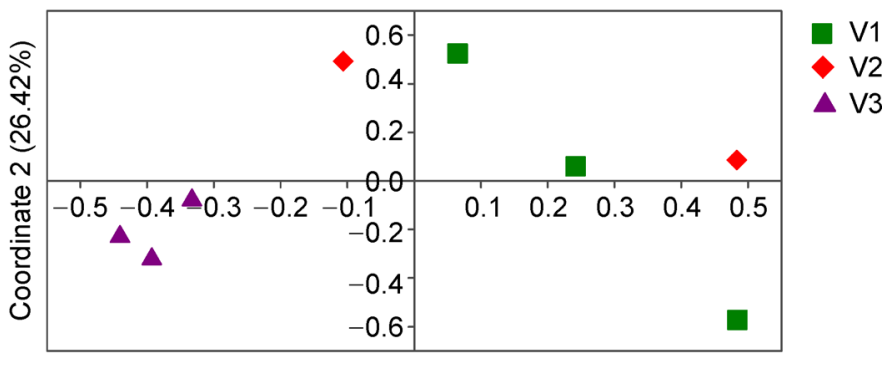

Coordinate $1(52.53 \%)$

Fig. 3 Principal coordinates analysis (PCoA) based on a Bray-Curtis dissimilarity matrix of the bacterial communities in soil (A) and litter (B) samples. OTUs $>0.5 \%$ in any of the soil samples and litter samples were included. V1, V2 and V3 correspond to $\mathrm{V}$. pompona, V. odorata and $V$. sp., respectively.

results in contrast to these were previously reported regarding phosphatase activity (Zhang et al., 2010; Steinauer et al., 2015). We hypothesize that the content of phenolic compounds in V3 microhabitat litter was lower than that in V1 and V2, which is consistent with evidence suggesting that phenol oxidase activity is dependent on the availability of phenolic compounds (Pind et al., 1994; Sinsabaugh 2010) and that the litter decomposition rate increases as the phenolic content decreases (Nicolai 1988; Torres et al., 2005).

In soil, the highest urease activity was found at the V3 site and had a positive correlation with plant richness. These data are inconsistent with previous findings about the interaction between plant richness and urease activity. While there is evidence for increased urease activity at the location of the highest plant species richness level (Zhang et al., 2010; Song et al., 2019), Steinauer et al. (2015) reported a lack of influence of plant diversity on urease activity. One explanation of the positive correlation reported here may be that an increase in plant richness diversifies and increases the soil nutrient pools and root exudate (Loranger-Merciris et al., 2006; Eisenhauer et al., 2017), thus putatively increasing the urease enzyme activity.

Similar to the work of Eisenhauer et al. (2017) and Chung et al. (2007), our study found a positive correlation between plant richness and fungal biomass in both litter and soil samples. Indeed, several studies have found that soil microbial biomass increases significantly with increasing plant diversity or richness (Steinauer et al., 2015; Khlifa et al., 2017; Zhang et al., 2019). In addition, it has been reported that plant richness can influence litter quality (i.e., nutrient content) and increase fine-root mortality underground, thus affecting the microbial biomass not only by altering the input of organic $\mathrm{C}$ and $\mathrm{N}$ in the soil (Kardol and Wardle, 2010; Huang et al., 2014; García-Franco et al., 2015; Zhang et al., 2016b; Chen et al., 2019), but also by promoting microbial biomass via root exudates (Eisenhauer et al., 2017). We additionally found that the biomass of microbial groups in the soil and litter responded differentially to plant richness. Thus, fungal biomass, but not bacterial biomass, positively correlated with plant richness. In agreement with our results,
Chung et al. (2007) reported no clear trend between soil bacterial biomass and plant richness. Furthermore, herein we report that plant richness was negatively correlated with litter bacterial diversity. Similar to our results, Schlatter et al. (2015) reported that plant communities with increased richness supported less diverse bacterial communities. Resembling the results obtained with plant richness, $\mathrm{DBH}$ also was positively correlated with fungal biomass and negatively correlated with bacterial richness in litter. Although there is a lack of information regarding the interaction of $\mathrm{DBH}$ with microbial biomass, activity, and diversity, it has been suggested that trees with larger $\mathrm{DBH}$ may have a stronger influence on the underground environment, such as producing more leaf and root litter or influencing the microclimate conditions (Saetre,1999).

\subsection{Composition of the microbial community}

Different microhabitats strongly influenced the litter fungal communities, in addition to the bacterial communities of both litter and soil. These results may be explained by differences in plant richness and $\mathrm{DBH}$, or litter and soil physiochemical properties, that created distinct microhabitats at each site. The composition of microbial communities in the soil and litter can be affected by the forest stand through its influence on abiotic factors (soil physiochemical properties) and litter quality (Nielsen et al., 2010; Landesman et al., 2014; Burns et al., 2015; Fu et al., 2015; Lladó et al., 2017; Wang et al., 2017). Soil physiochemical properties are primary drivers of microbial community composition (Wakelin et al., 2016; Dassen et al., 2017). Plant species also influence and drive their microbial communities in a species-specific manner (Dawson et al., 2017; Delgado-Baquerizo et al., 2018a). Moreover, Schlatter et al. (2015) reported that the composition of the soil bacterial community was significantly altered by an increase in plant richness.

\section{Conclusions}

Taken together, our work provides new insights into the effects 
of the distinct microhabitats on soil and litter microbial communities associated with wild relatives of Vanilla crop in a tropical rainforest, interactions that were heretofore unknown. Properties of the soil (EC, WSC, TOC, and N) and litter (moisture, WSC, and N), in addition to plant richness and $\mathrm{DBH}$, were identified as key driving factors causing differences between microhabitats in terms of enzyme activities, microbial biomass, diversity, and microbial community composition. Soil from tropical climates contain an enormous amount of organic $\mathrm{C}$ and host great biodiversity, and it is by far less characterized than that of other ecosystems (Tedersoo et al., 2014; Delgado-Baquerizo et al., 2018b). Therefore, further studies concerning the microbial ecology of the soil of tropical areas are needed. In particular, investigation of plant-microbial interactions and understanding the factors governing soil microbial diversity are of great concern when dealing with economically valuable species such as Vanilla species in nearly pristine areas of tremendous ecological value, including those found in tropical ecosystems. In conclusion, our findings are relevant to justify performing actions for effective conservation of Vanilla spp. diversity and to develop management strategies in ex situ and in situ production systems for this plant.

\section{Acknowledgments}

The authors are grateful to the Osa Conservation Organization for allowing access for sampling at Piro Biological Station. They are also grateful to the Spanish Ministry of Science and the Spanish Research Council (CSIC) call "I-COOP Suelos y Legumbres 2016" for the funded project (2016SU0013). This work was supported by the Universidad Nacional, Costa Rica (grant number SIA-0249-18). This study was performed with permission from Costa Rica's Ministry of Environment and Energy (R-0022019-OT-CONAGEBIO)..

\section{Electronic supplementary material}

Supplementary material is available in the online version of this article at https://doi.org/10.1007/s42832-020-0041-7 and is accessible for authorized users.

\section{References}

Allison, S.D., Jastrow, J.D., 2006. Activities of extracellular enzymes in physically isolated fractions of restored grassland soils. Soil Biology \& Biochemistry 38, 3245-3256.

Alomia, Y.A., Mosquera-Espinosa, A.T., Flanagan, N.S., Otero, J.T., 2017. Seed viability and symbiotic seed germination in Vanilla spp. (Orchidaceae). Research Journal of Seed Science 10, 43-52.

Anderson, M.J., 2001. A new method for non-parametric multivariate analysis of variance. Austral Ecology 26, 32-46.

Aronesty, E., 2013. Comparison of sequencing utility programs. Open Bioinformatics Journal 7, 1-8.

Azofeifa-Bolaños, J., Gigant, L.R., Nicolás-García, M., Pignal, M.,
Tavares-González, F.B., Hágsater, E., Salazar-Chávez, G.A., Reyes-López, D., Archila-Morales, F.L., García-García, J.A., da Silva, D., Allibert, A., Solano-Campos, F., Rodríguez-Jimenes, G. del C., Paniagua-Vásquez, A., Besse, P., Pérez-Silva, A., Grisoni, M., 2017. A new vanilla species from Costa Rica closely related to V. planifolia (Orchidaceae). European Journal of Taxonomy 284, $1-26$.

Azofeifa-Bolaños, J.B., Paniagua-Vásquez, A., García-García, J.A., 2014. Importancia y desafíos de la conservación de Vanilla spp. (Orchidaceae) en Costa Rica. Agronomía Mesoamericana 25, 189-202.

Azofeifa-Bolaños, J.B., Rivera-Coto, G., Paniagua-Vasquez, A., Cordero-Solórzano, R., 2018. Selección cualitativa del esqueje en la sobreviviencia y desarrollo morfogenético de Vanilla planifolia Andrews. Agronomía Mesoamericana 29, 619-627.

Bardgett, R.D., Mommer, L., De Vries, F.T., 2014. Going underground: Root traits as drivers of ecosystem processes. Trends in Ecology \& Evolution 29, 692-699.

Bastida, F., Torres, I.F., Moreno, J.L., Baldrian, P., Ondoño, S., RuizNavarro, A., Hernández, T., Richnow, H.H., Starke, R., García, C., Jehmlich, N., 2016. The active microbial diversity drives ecosystem multifunctionality and is physiologically related to carbon availability in Mediterranean semi-arid soils. Molecular Ecology 25, $4660-4673$.

Bligh, E.G., Dyer, W.J., 1959. A rapid method for total lipid extraction and purification. Canadian Journal of Biochemistry and Physiology 37, 911-917.

Bradford, M.A., Wieder, W.R., Bonan, G.B., Fierer, N., Raymond, P.A., Crowther, T.W., 2016. Managing uncertainty in soil carbon feedbacks to climate change. Nature Climate Change 6, 751-758.

Brant, J.B., Sulzman, E.W., Myrold, D.D., 2006. Microbial community utilization of added carbon substrates in response to long-term carbon input manipulation. Soil Biology \& Biochemistry 38, 22192232.

Burns, J.H., Anacker, B.L., Strauss, S.Y., Burke, D.J., 2015. Soil microbial community variation correlates most strongly with plant species identity, followed by soil chemistry, spatial location and plant genus. AoB Plants 7, 1-10.

Cabugao, K.G., Timm, C.M., Carrell, A.A., Childs, J., Lu, T.Y.S., Pelletier, D.A., Weston, D.J., Norby, R.J., 2017. Root and rhizosphere bacterial phosphatase activity varies with tree species and soil phosphorus availability in Puerto Rico tropical forest. Frontiers of Plant Science 8, 1-14.

Caporaso, J.G., Lauber, C.L., Walters, W.A., Berg-Lyons, D., Huntley, J., Fierer, N., Owens, S.M., Betley, J., Fraser, L., Bauer, M., Gormley, N., Gilbert, J.A., Smith, G., Knight, R., 2012. Ultra-highthroughput microbial community analysis on the Illumina HiSeq and MiSeq platforms. ISME Journal 6, 1621-1624.

Chen, L., Xiang, W., Wu, H., Ouyang, S., Zhou, B., Zeng, Y., Chen, Y., Kuzyakov, Y., 2019. Tree species identity surpasses richness in affecting soil microbial richness and community composition in subtropical forests. Soil Biology \& Biochemistry 130, 113-121.

Chung, H., Zak, D.R., Reich, P.B., Ellsworth, D.S., 2007. Plant species richness, elevated $\mathrm{CO}_{2}$, and atmospheric nitrogen deposition alter soil microbial community composition and function. Global Change Biology 13, 980-989. 
Cole, J.R., Wang, Q., Fish, J.A., Chai, B., McGarrell, D.M., Sun, Y., Brown, C.T., Porras-Alfaro, A., Kuske, C.R., Tiedje, J.M., 2014. Ribosomal Database Project: Data and tools for high throughput rRNA analysis. Nucleic Acids Research 42, 633-642.

Dassen, S., Cortois, R., Martens, H., de Hollander, M., Kowalchuk, G. A., van der Putten, W.H., De Deyn, G.B., 2017. Differential responses of soil bacteria, fungi, archaea and protists to plant species richness and plant functional group identity. Molecular Ecology 26, 4085-4098.

Dawson, W., Hör, J., Egert, M., van Kleunen, M., Peste, M., 2017. A small number of low-abundance bacteria dominate plant speciesspecific responses during rhizosphere colonization. Frontiers in Microbiology 8, 1-13.

Delgado-Baquerizo, M., Fry, E.L., Eldridge, D.J., de Vries, F.T., Manning, P., Hamonts, K., Kattge, J., Boenisch, G., Singh, B.K., Bardgett, R.D., 2018a. Plant attributes explain the distribution of soil microbial communities in two contrasting regions of the globe. New Phytologist 219, 574-587.

Delgado-Baquerizo, M., Oliverio, A.M., Brewer, T.E., BenaventGonzález, A., Eldridge, D.J., Bardgett, R.D., Maestre, F.T., Singh, B.K., Fierer, N., 2018b. A global atlas of the dominant bacteria found in soil. Science 359, 320-325.

Dungait, J.A.J., Kemmitt, S.J., Michallon, L., Guo, S., Wen, Q., Brookes, P.C., Evershed, R.P., 2011. Variable responses of the soil microbial biomass to trace concentrations of ${ }^{13} \mathrm{C}$-labelled glucose, using ${ }^{13}$ C-PLFA analysis. European Journal of Soil Science 62, 117-126.

Edgar, R.C., 2013. UPARSE: Highly accurate OTU sequences from microbial amplicon reads. Nature Methods 10, 996-998.

Eisenhauer, N., Lanoue, A., Strecker, T., Scheu, S., Steinauer, K. Thakur, M.P., Mommer, L., 2017. Root biomass and exudates link plant diversity with soil bacterial and fungal biomass. Scientific Reports 7, 1-8.

Eivazi, F., Tabatabai, M.A., 1977. Phosphatases in soils. Soil Biology \& Biochemistry 9, 167-172.

Frostegård, Å., Bååth, E., Tunlio, A., 1993. Shifts in the structure of soil microbial communities in limed forests as revealed by phospholipid fatty acid analysis. Soil Biology \& Biochemistry 25 , 723-730.

Fu, X., Yang, F., Wang, J., Di, Y., Dai, X., Zhang, X., Wang, H., 2015. Understory vegetation leads to changes in soil acidity and in microbial communities 27 years after reforestation. Science of the Total Environment 502, 280-286.

García-Franco, N., Martínez-Mena, M., Goberna, M., Albaladejo, J., 2015. Changes in soil aggregation and microbial community structure control carbon sequestration after afforestation of semiarid shrublands. Soil Biology \& Biochemistry 87, 110-121.

Guangming, L., Xuechen, Z., Xiuping, W., Hongbo, S., Jingsong, Y., Xiangping, W., 2017. Soil enzymes as indicators of saline soil fertility under various soil amendments. Agriculture, Ecosystems \& Environment 237, 274-279.

Haichar, F., Santaella, C., Heulin, T., Achouak, W., 2014. Root exudates mediated interactions belowground. Soil Biology \& Biochemistry 77, 69-80.

Hammer, Ø., Harper, D., Ryan, P., 2001. Past: paleontological statistics software package for education and data analysis.
Palaeontologia Electronica 4, 1-9.

Hartmann, A., Schmid, M., van Tuinen, D., Berg, G., 2009. Plantdriven selection of microbes. Plant and Soil 321, 235-257.

Hortal, S., Lozano, Y.M., Bastida, F., Armas, C., Moreno, J.L., Garcia, C., Pugnaire, F.I., 2017. Plant-plant competition outcomes are modulated by plant effects on the soil bacterial community. Scientific Reports 7, 1-9.

Huang, X., Liu, S., Wang, H., Hu, Z., Li, Z., You, Y., 2014. Changes of soil microbial biomass carbon and community composition through mixing nitrogen-fixing species with Eucalyptus urophylla in subtropical China. Soil Biology \& Biochemistry 73, 42-48.

Ihrmark, K., Bödeker, I.T.M., Cruz-Martinez, K., Friberg, H., Kubartova, A., Schenck, J., Strid, Y., Stenlid, J., Brandström-Durling, M., Clemmensen, K.E., Lindahl, B.D., 2012. New primers to amplify the fungal ITS2 region- evaluation by 454-sequencing of artificial and natural communities. FEMS Microbiology Ecology 82, 666677

IUSS Working Group WRB, 2015. World Reference Base for Soil Resources 2014, update 2015. International soil classification system for naming soils and creating legends for soil maps. FAO, Rome.

Iwaoka, C., Imada, S., Taniguchi, T., Du, S., Yamanaka, N., Tateno, R., 2018. The impacts of soil fertility and salinity on soil nitrogen dynamics mediated by the soil microbial community beneath the halophytic shrub tamarisk. Microbial Ecology 75, 985-996.

John, R., Dalling, J.W., Harms, K.E., Yavitt, J.B., Stallard, R.F., Mirabello, M., Hubbell, S.P., Valencia, R., Navarrete, H., Vallejo, M., Foster, R.B., 2007. Soil nutrients influence spatial distributions of tropical trees species. Proceedings of the National Academy of Sciences of the United States of America 104, 864-869.

Kandeler, E., Gerber, H., 1988. Short-term assay of soil urease activity using colorimetric determination of ammonium. Biology and Fertility of Soils 6, 68-72.

Kardol, P., Wardle, D.A., 2010. How understanding abovegroundbelowground linkages can assist restoration ecology. Trends in Ecology \& Evolution 25, 670-679.

Karremans, A.P., Lehmann, C., 2018. A highly threatened new species of Vanilla from Costa Rica. Lindleyana 87, 304-307.

Khlifa, R., Paquette, A., Messier, C., Reich, P.B., Munson, A.D., 2017. Do temperate tree species diversity and identity influence soil microbial community function and composition? Ecology and Evolution 7, 7965-7974.

Kivlin, S.N., Hawkes, C.V., 2016. Temporal and spatial variation of soil bacteria richness, composition, and function in a neotropical rainforest. PLoS One 11, 1-17.

Koljalg, U., Nilsson, R.H., Abarenkov, K., Tedersoo, L., Taylor, A.F.S., Bahram, M., Bates, S.T., Bruns, T.D., Bengtsson-Palme, J., Callaghan, T.M., Douglas, B., Drenkhan, T., Eberhardt, U., Dueñas, M., Grebenc, T., Griffith, G.W., Hartmann, M., Kirk, P.M., Kohout, P., Larsson, E., Lindahl, B.D., Lücking, R., Martín, M.P., Matheny, P.B., Nguyen, N.H., Niskanen, T., Oja, J., Peay, K.G., Peintner, U., Peterson, M., Põldmaa, K., Saag, L., Saar, I., Schüßler, A., Scott, J.A., Senés, C., Smith, M.E., Suija, A., Taylor, D.L., Telleria, M.T., Weiss, M., Larsson, K.H., 2014. Towards a unified paradigm for sequence-based identification of fungi. Molecular Ecology 22, 5271-5277. 
Korthou, H., Verpoorte, R., 2007. Vanilla. In: Berger, R.G., ed. Flavours and fragrances: Chemistry, bioprocessing and sustainability. Berlin: Springer-Verlag, 203-217.

Landesman, W.J., Nelson, D.M., Fitzpatrick, M.C., 2014. Soil properties and tree species drive $\beta$-diversity of soil bacterial communities. Soil Biology \& Biochemistry 76, 201-209.

Lange, M., Habekost, M., Eisenhauer, N., Roscher, C., Bessler, H., Engels, C., Oelmann, Y., Scheu, S., Wilcke, W., Schulze, E.D., Gleixner, G., 2014. Biotic and abiotic properties mediating plant diversity effects on soil microbial communities in an experimental grassland. PLoS One 9, e96182.

Leff, J.W., Nemergut, D.R., Grandy, A.S., O’Neill, S.P., Wickings, K., Townsend, A.R., Cleveland, C.C., 2012. The effects of soil bacterial community structure on decomposition in a tropical rain forest. Ecosystems (New York, N.Y.) 15, 284-298.

Lemanowicz, J., 2018. Dynamics of phosphorus content and the activity of phosphatase in forest soil in the sustained nitrogen compounds emissions zone. Environmental Science and Pollution Research International 25, 33773-33782.

Lemanowicz, J., Bartkowiak, A., 2016. Changes in the activity of phosphatase and the content of phosphorus in salt-affected soils grassland habitat natura 2000. Polish Journal of Soil Science 49, 149-165.

Liu, X., Liang, M., Etienne, R.S., Wang, Y., Staehelin, C., Yu, S., 2012. Experimental evidence for a phylogenetic Janzen-Connell effect in a subtropical forest. Ecology Letters 15, 111-118.

Liu, Y., Sun, X., Li, S., Li, S., Zhou, W., Ma, Q., Zhang, J., 2019. Influence of green waste compost on $\mathrm{Pb}$-polluted soil remediation, soil quality improvement, and uptake by Pakchoi cabbage (Brassica campestris L. ssp). Environmental Science and Pollution Research International.

Lladó, S., López-Mondéjar, R., Baldrian, P., 2017. Forest soil bacteria: Diversity, involvement in ecosystem processes, and response to global change. Microbiology and Molecular Biology Reviews 81, e00063-e16.

Looby, C.I., Treseder, K.K., 2018. Shifts in soil fungi and extracellular enzyme activity with simulated climate change in a tropical montane cloud forest. Soil Biology \& Biochemistry 117, 87-96.

Loranger-Merciris, G., Barthes, L., Gastine, A., Leadley, P., 2006. Rapid effects of plant species diversity and identity on soil microbial communities in experimental grassland ecosystems. Soil Biology \& Biochemistry 38, 2336-2343.

Lozano, Y.M., Armas, C., Hortal, S., Casanoves, F., Pugnaire, F.I., 2017. Disentangling above- and below-ground facilitation drivers in arid environments: the role of soil microorganisms, soil properties and microhabitat. New Phytologist 216, 1236-1246.

Luo, X., Fu, X., Yang, Y., Cai, P., Peng, S., Chen, W., Huang, Q., 2016. Microbial communities play important roles in modulating paddy soil fertility. Scientific Reports 6, 1-12.

Margalef, O., Sardans, J., Fernández-Martínez, M., Molowny-Horas, R., Janssens, I.A., Ciais, P., Goll, D., Richter, A., Obersteiner, M., Asensio, D., Peñuelas, J., 2017. Global patterns of phosphatase activity in natural soils. Scientific Reports 7, 1-13.

Maruenda, H., Vico, M.D.L., Householder, J.E., Janovec, J.P., Cañari, C., Naka, A., Gonzalez, A.E., 2013. Exploration of Vanilla pompona from the Peruvian Amazon as a potential source of vanilla essence: Quantification of phenolics by HPLC-DAD. Food Chemistry 138, 161-167.

Mazzon, M., Cavani, L., Margon, A., Sorrenti, G., Ciavatta, C., Marzadori, C., 2018. Changes in soil phenol oxidase activities due to long-term application of compost and mineral $\mathrm{N}$ in a walnut orchard. Geoderma 316, 70-77.

McCarthy-Neumann, S., Kobe, R.K., 2010. Conspecific plant-soil feedbacks reduce survivorship and growth of tropical tree seedlings. Journal of Ecology 98, 396-407.

McGee, K.M., Eaton, W.D., Shokralla, S., Hajibabaei, M., 2018. Determinants of soil bacterial and fungal community composition toward carbon-use efficiency across primary and secondary forests in a Costa Rican conservation area. Microbial Ecology 77, 148-167.

Nemergut, D.R., Cleveland, C.C., Wieder, W.R., Washenberger, C.L., Townsend, A.R., 2010. Plot-scale manipulations of organic matter inputs to soils correlate with shifts in microbial community composition in a lowland tropical rain forest. Soil Biology \& Biochemistry 42, 2153-2160.

Nicolai, V., 1988. Phenolic and mineral content of leaves influences decomposition in European Forest Ecosystems. Oecologia 75, 575-579.

Nielsen, U.N., Osler, G.H.R., Campbell, C.D., Burslem, D.F.R.P., van der Wal, R., 2010. The influence of vegetation type, soil properties and precipitation on the composition of soil mite and microbial communities at the landscape scale. Journal of Biogeography 37 , 1317-1328.

Ochoa-Hueso, R., Eldridge, D.J., Delgado-Baquerizo, M., Soliveres, S., Bowker, M.A., Gross, N., Le Bagousse-Pinguet, Y., Quero, J.L., García-Gómez, M., Valencia, E., Arredondo, T., Beinticinco, L., Bran, D., Cea, A., Coaguila, D., Dougill, A.J., Espinosa, C.I., Gaitán, J., Guuroh, R.T., Guzman, E., Gutiérrez, J.R., Hernández, R.M., Huber-Sannwald, E., Jeffries, T., Linstädter, A., Mau, R.L., Monerris, J., Prina, A., Pucheta, E., Stavi, I., Thomas, A.D., Zaady, E., Singh, B.K., Maestre, F.T., 2018. Soil fungal abundance and plant functional traits drive fertile island formation in global drylands. Journal of Ecology 106, 242-253.

Oksanen, J., Blanchet, F.G., Friendly, M., Kindt, R., Legendre, P., McGlinn, D., Minchin, P.R., O'Hara, R.B., Simpson, G.L., Solymos, P., Stevens, M.H.H., Szoecs, E., Wagner, H., 2019. vegan: Community Ecology Package. R package version2.5-6. https:// CRAN.R-project.org/package = vegan .

Ondoño, S., Bastida, F., Moreno, J.L., 2014. Microbiological and biochemical properties of artificial substrates: A preliminary study of its application as Technosols or as a basis in Green Roof Systems. Ecological Engineering 70, 189-199.

Pind, A., Freeman, C., Lock, M.A., 1994. Enzymic degradation of phenolic materials in peatlands-measurement of phenol oxidase activity. Plant and Soil 159, 227-231.

Prather, C., Strickland, M.S., Laws, A., Branson, D., 2017. Herbivore species identity and composition affect soil enzymatic activity through altered plant composition in a coastal tallgrass prairie. Soil Biology \& Biochemistry 112, 277-280.

Prober, S.M., Leff, J.W., Bates, S.T., Borer, E.T., Firn, J., Harpole, W. S., Lind, E.M., Seabloom, E.W., Adler, P.B., Bakker, J.D., Cleland, E.E., Decrappeo, N.M., Delorenze, E., Hagenah, N., Hautier, Y., 
Hofmockel, K.S., Kirkman, K.P., Knops, J.M.H., La Pierre, K.J., Macdougall, A.S., Mcculley, R.L., Mitchell, C.E., Risch, A.C., Schuetz, M., Stevens, C.J., Williams, R.J., Fierer, N., 2015. Plant diversity predicts beta but not alpha diversity of soil microbes across grasslands worldwide. Ecology Letters 18, 85-95.

R Core Team, (2019). R: A language and environment for statistical computing. R Foundation for Statistical Computing, Vienna, Austria. URL https://www.R-project.org/.

Ramirez, K.S., Knight, C.G., De Hollander, M., Brearley, F.Q., Constantinides, B., Cotton, A., Creer, S., Crowther, T.W., Davison, J., Delgado-Baquerizo, M., Dorrepaal, E., Elliott, D.R., Fox, G., Griffiths, R.I., Hale, C., Hartman, K., Houlden, A., Jones, D.L., Krab, E.J., Maestre, F.T., Mcguire, K.L., Monteux, S., Orr, C.H., Van Der Putten, W.H., Roberts, I.S., Singh, B.K., Straathof, A.L., Bhatnagar, J.M., Thion, C., 2017. Detecting macroecological patterns in bacterial communities across independent studies of global soils. Nature Microbiology 3, 189-196.

Ranadive, A., 2011. Quality control of vanilla beans and extracts. In: Havkin-Frenkel, D., Belanger, F., eds. Handbook of Vanilla Science and Technology. New Jersey: Wiley-Blackwell, 141-161.

Rinnan, R., Bååth, E., 2009. Differential utilization of carbon substrates by bacteria and fungi in tundra soil. Applied and Environmental Microbiology 75, 3611-3620.

Saetre, P., 1999. Spatial patterns of ground vegetation, soil microbial biomass and activity in a mixed spruce-birch stand. Ecography 22 , 183-192.

Saha, S., Gopinath, K.A., Mina, B.L., Gupta, H.S., 2008. Influence of continuous application of inorganic nutrients to a Maize-Wheat rotation on soil enzyme activity and grain quality in a rainfed Indian soil. European Journal of Soil Biology 44, 521-531.

Schilling, E.M., Waring, B.G., Schilling, J.S., Powers, J.S., 2016. Forest composition modifies litter dynamics and decomposition in regenerating tropical dry forest. Oecologia 182, 287-297.

Schlatter, D.C., Bakker, M.G., Bradeen, J.M., Kinkel, L.L., 2015. Plant community richness and microbial interactions structure bacterial communities in soil. Ecology 96, 134-142.

Si, P., Shao, W., Yu, H., Yang, X., Gao, D., Qiao, X., Wang, Z., Wu, G., 2018. Rhizosphere microenvironments of eight common deciduous fruit trees were shaped by microbes in northern China. Frontiers in Microbiology 9, 1-17.

Singh, K., 2016. Microbial and enzyme activities of saline and sodic soils. Land Degradation \& Development 27, 706-718.

Sinsabaugh, R.L., 2010. Phenol oxidase, peroxidase and organic matter dynamics of soil. Soil Biology \& Biochemistry 42, 391-404.

Smith, A.P., Marín-Spiotta, E., Balser, T., 2015. Successional and seasonal variations in soil and litter microbial community structure and function during tropical postagricultural forest regeneration: A multiyear study. Global Change Biology 21, 3532-3547.

Song, Y., Song, C., Shi, F., Wang, M., Ren, J., Wang, X., Jiang, L., 2019. Linking plant community composition with the soil $C$ pool, $N$ availability and enzyme activity in boreal peatlands of Northeast China. Applied Soil Ecology 140, 144-154.

Steinauer, K., Tilman, D., Wragg, P.D., Cesarz, S., Cowles, J.M., Pritsch, K., Reich, P.B., Weisser, W.W., Eisenhauer, N., 2015. Plant diversity effects on soil microbial functions and enzymes are stronger than warming in a grassland experiment. Ecology 96, 99
112.

Štursova, M., Bárta, J., Šantručková, H., Baldrian, P., 2016. Smallscale spatial heterogeneity of ecosystem properties, microbial community composition and microbial activities in a temperate mountain forest soil. FEMS Microbiology Ecology 92, 1-10.

Tabatabai, M.A., Bremner, J.M., 1969. Use of p-nitrophenyl phosphate for assay of soil phosphatase activity. Soil Biology \& Biochemistry 1, 301-307.

Tedersoo, L., Bahram, M., Põlme, S., Kõljalg, U., Yorou, N.S., Wijesundera, R., Ruiz, L.V., Vasco-Palacios, A.M., Thu, P.Q., Suija, A., Smith, M.E., Sharp, C., Saluveer, E., Saitta, A., Rosas, M., Riit, T., Ratkowsky, D., Pritsch, K., Põldmaa, K., Piepenbring, M., Phosri, C., Peterson, M., Parts, K., Pärtel, K., Otsing, E., Nouhra, E., Njouonkou, A.L., Nilsson, R.H., Morgado, L.N., Mayor, J., May, T.W., Majuakim, L., Lodge, D.J., Lee, S.S., Larsson, K.H., Kohout, P., Hosaka, K., Hiiesalu, I., Henkel, T.W., Harend, H., Guo, L., Greslebin, A., Grelet, G., Geml, J., Gates, G., Dunstan, W., Dunk, C., Drenkhan, R., Dearnaley, J., De Kesel, A., Dang, T., Chen, X., Buegger, F., Brearley, F.Q., Bonito, G., Anslan, S., Abell, S., Abarenkov, K., 2014. Global diversity and geography of soil fungi. Science 346, 1256688

Tianzhu, L., Guicai, S., Jian, W., Gengxin, Z., 2017. Microbial communities and associated enzyme activities in alpine wetlands with increasing altitude on the Tibetan Plateau. Wetlands 37, 401412.

Torres, P.A., Abril, A.B., Bucher, E.H., 2005. Microbial succession in litter decomposition in the semi-arid Chaco woodland. Soil Biology \& Biochemistry $37,49-54$

Van Nuland, M.E., Wooliver, R.C., Pfennigwerth, A.A., Read, Q.D., Ware, I.M., Mueller, L., Fordyce, J.A., Schweitzer, J.A., Bailey, J.K., 2016. Plant-soil feedbacks: connecting ecosystem ecology and evolution. Functional Ecology 30, 1032-1042.

Větrovský, T., Baldrian, P., Morais, D., 2018. SEED 2: A user-friendly platform for amplicon high-throughput sequencing data analyses. Bioinformatics (Oxford, England) 34, 2292-2294.

Wakelin, S.A., Gerard, E., van Koten, C., Banabas, M., O'Callaghan, M., Nelson, P.N., 2016. Soil physicochemical properties impact more strongly on bacteria and fungi than conversion of grassland to oil palm. Pedobiologia 59, 83-91.

Wang, X.Y., Ge, Y., Wang, J., 2017. Positive effects of plant diversity on soil microbial biomass and activity are associated with more root biomass production. Journal of Plant Interactions 12, 533541.

Waring, B.G., 2013. Exploring relationships between enzyme activities and leaf litter decomposition in a wet tropical forest. Soil Biology \& Biochemistry 64, 89-95.

Waring, B.G., Adams, R., Branco, S., Powers, J.S., 2016. Scaledependent variation in nitrogen cycling and soil fungal communities along gradients of forest composition and age in regenerating tropical dry forests. New Phytologist 209, 845-854.

Watteyn, C., Fremout, T., Karremans, A.P., Huarcaya, R.P., Azofeifa, J.B., Reubens, B., Muys, B., 2020. Vanilla distribution modeling for conservation and sustainable cultivation in a joint land sparing/ sharing concept. Ecosphere 11, e03056.

Wei, K., Sun, T., Tian, J., Chen, Z., Chen, L., 2018. Soil microbial biomass, phosphatase and their relationships with phosphorus 
turnover under mixed inorganic and organic nitrogen addition in a Larix gmelinii plantation. Forest Ecology and Management 422, 313-322.

Wu, N., Li, Z., Wu, F., Tang, M., 2019. Microenvironment and microbial community in the rhizosphere of dioecious Populus cathayana at Chaka Salt Lake. Journal of Soils and Sediments 19, 27402751.

Xie, E., Ding, A., Zheng, L., Lu, C., Wang, J., Huang, B., Xiu, H., 2016. Seasonal variation in populations of nitrogen-transforming bacteria and correlation with nitrogen removal in a full-scale horizontal flow constructed wetland treating polluted river water. Geomicrobiology Journal 33, 338-346.

Xiong, W., Zhao, Q., Xue, C., Xun, W., Zhao, J., Wu, H., Li, R., Shen, Q., 2016. Comparison of fungal community in black pepper-vanilla and vanilla monoculture systems associated with vanilla Fusarium wilt disease. Frontiers in Microbiology 7, 1-8.

Yao, Q., Li, Z., Song, Y., Wright, S.J., Guo, X., Tringe, S.G., Tfaily, M. M., Paša-Tolić, L., Hazen, T.C., Turner, B.L., Mayes, M.A., Pan, C., 2018. Community proteogenomics reveals the systemic impact of phosphorus availability on microbial functions in tropical soil. Nature Ecology \& Evolution 2, 499-509.

Zhang, C., Wang, J., Liu, G., Song, Z., Fang, L., 2019. Impact of soil leachate on microbial biomass and diversity affected by plant diversity. Plant and Soil 439, 505-523.

Zhang, C.B., Wang, J., Liu, W.L., Zhu, S.X., Liu, D., Chang, S.X., Chang, J., Ge, Y., 2010. Effects of plant diversity on nutrient retention and enzyme activities in a full-scale constructed wetland. Bioresource Technology 101, 1686-1692.

Zhang, Q., Wu, J., Yang, F., Lei, Y., Zhang, Q., Cheng, X., 2016a. Alterations in soil microbial community composition and biomass following agricultural land use change. Scientific Reports 6, 1-10.

Zhang, T., Zhang, J., Wang, T., Tian, X., Ge, H., Ma, Y., Wang, K., 2016b. Effects of organic matter on Leymus chinensis germination, growth, and urease activity and available nitrogen in coastal saline soil. Toxicological and Environmental Chemistry 98, 623-629.

Zhang, W., Qiao, W., Gao, D., Dai, Y., Deng, J., Yang, G., Han, X., Ren, G., 2018. Relationship between soil nutrient properties and biological activities along a restoration chronosequence of Pinus tabulaeformis plantation forests in the Ziwuling Mountains, China. Catena 161, 85-95.

Žifcááková, L., Větrovský, T., Howe, A., Baldrian, P., 2016. Microbial activity in forest soil reflects the changes in ecosystem properties between summer and winter. Environmental Microbiology 18, 288 301. 